Article

\title{
Consumers' Fears Regarding Food Availability and Purchasing Behaviors during the COVID-19 Pandemic: The Importance of Trust and Perceived Stress
}

\author{
Marzena Jeżewska-Zychowicz *®i), Marta Plichta@ and Maria Królak@ \\ Department of Food Market and Consumer Research, Institute of Human Nutrition Sciences, Warsaw University \\ of Life Sciences (SGGW-WULS), Nowoursynowska 159C, 02-776 Warsaw, Poland; \\ marta_plichta@sggw.edu.pl (M.P.); maria.krolak@gmail.com (M.K.) \\ * Correspondence: marzena_jezewska_zychowicz@sggw.edu.pl; Tel.: +48-22-59-37-131
}

Received: 3 August 2020; Accepted: 15 September 2020; Published: 17 September 2020

\begin{abstract}
The present study aimed to investigate whether trust in circulating information and perceived stress are predictors of consumers' fear of limited access to food as well as predictors of food purchase behaviors during the COVID-19 pandemic. The computer-assisted web interviewing (CAWI) technique was used to collect data from 1033 Polish adults in March 2020. Logistic regression was used to estimate the likelihood of fear of limited access to food and the likelihood of purchase of larger amounts of food than usual. The likelihood of experiencing fear of limited access to food increased by $16 \%$ with higher perceived stress, by 50\% with higher trust in "Mass media and friends", and by $219 \%$ with perceived changes in food availability in the previous month. Trust in "Polish government institutions" decreased the chance of experiencing such fears by $22 \%$. The likelihood of purchasing larger quantities of food than usual increased by $9 \%$ with higher perceived stress, by $46 \%$ with higher trust in "Mass media and friends", by $81 \%$ with perceived changes in food availability in the last month, and by $130 \%$ with fears of limited access to food as the pandemic spreads. Government institutions may have difficulty in disseminating pandemic-related recommendations through media, not only due to relatively low trust people have in media organizations but also due to the increasing likelihood of the occurrence of both fears regarding food availability and panic-stricken food-buying behaviors with increase in trust in this source of information. Therefore, it is necessary to develop interventions that will reduce perceived stress and improve the trust in information from reputable sources.
\end{abstract}

Keywords: COVID-19 pandemic; food purchase; consumer; trust; fears; perceived stress

\section{Introduction}

The appearance of SARS-CoV-2 in late December 2019 in Wuhan triggered a new, rapidly evolving situation, with the spread of the virus outside China. In March 2020, the vast spread of the COVID-19 disease in the world qualified it as a global pandemic [1]. In most countries, legal regulations were introduced to slow down the virus spread [2], including the order of social isolation (lockdown), use of masks, travel restrictions, etc. [3]. In Poland, an epidemic threat was announced on 12 March 2020, followed by the announcement of the state of pandemic on 20 March 2020. Along with the changes in the legal regulations, significant changes occurred in the food market. From 11 March 2020 onward, the turnover in grocery stores rocketed, queues increased, and shortages of goods began to appear. The Ministry of Development attempted to calm concerns regarding food shortages by providing information that denied rumors about the closure of retail outlets or the placement of sanitary cordons around cities [4]. The use of face masks was made mandatory only on 16 April 2020. Generally, restrictions 
in force in Poland and other countries inevitably caused public concerns, which were further magnified by mass media and social media coverage, misinformation, and pseudoscience [5-8].

For the majority of Poles, grocery stores became one of the few public places visited during the lockdown. Thus, shopping for food could increase the risk of contracting SARS-CoV-2 infection due to sharing of indoor space [9-11]. Previous studies have revealed that consumers feared contracting SARS-CoV-2 infection during grocery shopping [12,13]. In addition to this perceived fear, strong concerns about the availability of food favored increased purchasing activity, which led to short-term shortages of food and cleaning products, the so-called empty shelves, which Poles have already experienced before during the 1970s and the 1980s [14]. As in other countries, to calm the situation, government institutions persuaded citizens that supplies were maintained at a level that ensured access to food and other products $[15,16]$. Mass media were active in broadcasting information regarding pandemic and food supplies [17]. Although real shortages in access to food appeared briefly, mental and social functioning was significantly deteriorated due to stress arising from many unknowns, also related to access to food, social isolation, unusual work mode, and information flood $[15,18,19]$.

During the COVID-19 pandemic, many people were forced to quarantine themselves at home, resulting in a high prevalence of psychological distress [20]. This stress was intensified by mass media that informed widely about the rapid increase in morbidity and mortality and the limited availability of diagnostic tests [21]. Thus, exploring consumers' fears, perceived stress, and uncertainties about some aspects of food situation in the COVID-19 pandemic is desirable for many reasons. Changes in people's food purchase patterns and food consumption due to social isolation directives as well as uncertainty about future may increase their fears uncontrollably and may affect eating patterns in various ways $[13,22]$. Changes in purchase patterns, e.g., bulk buying of foods, may lead to consuming food that is no longer safe, while stockpiling may lead to certain foods being available in stores in a very limited supply. Moreover, not only binge-eating but also consumption of palatable foods, snacking, and alcohol consumption may appear [23].

In a situation of uncertainty, appropriate communication about the situation concerning the COVID-19 pandemic becomes crucial for citizens [24]; this is because the public has limited knowledge about the infection and the modes of its spread [25]. Simultaneously, the loss of trust in information provided by government agencies as well as by doctors or nutritionists on TV or social media is observed [26]. Thus, enhancing trust in government and health authorities is required for a greater focus [27]. Trust is understood as a level of subjective probability with which the public (trustor) assesses that the other agent (trustee) will perform a particular action and the context that affects trustor's action [28] is critical in situations where perceived risk and/or lack of knowledge occur [29]. According to Giddens [30], trust leads to consciously or subconsciously making a "leap of faith," i.e., acknowledging that the expertise required to address the lack is held by another individual or system. Receiving information can affect the public's knowledge about perceived risk, thereby influencing their decisions to adopt protective measures [31,32]. However, public response to communication efforts may be shaped less by explanations of uncertainty than by trust in the parties involved [25,33]. It is, therefore, important to understand how the public perceives the situation and to what degree they trust different agents that inform them about uncertainty resulting from the COVID-19 pandemic [31,34]. The Trust and Confidence Model suggests that people with higher levels of trust or confidence in institutions are more likely to accept recommended measures than those with lower trust or confidence levels $[35,36]$. Studies examining the H5N1 influenza indicated that trust not only in health agencies but also in government and media positively influenced people's willingness to adopt precautionary behavior during a pandemic [37-39]; however, the abundance of information or conflicting messages can decrease public trust [36].

Learning about food purchasing behavior is vital not only to understand how the behavior of consumers changes under stressful conditions but also to provide useful guidance for some management efforts. However, public trust in available information is crucial in order to succeed in the efforts undertaken. To address the abovementioned issues, the present study aimed to investigate whether 
trust in information and perceived stress are predictors of consumers' fears regarding limited access to food as the pandemic spreads and predictors of food purchase behaviors during the COVID-19 pandemic. We hypothesized that higher trust in the source of information and lower levels of perceived stress protect a person from experiencing fear regarding unavailability of food as well as from buying large amounts of food.

\section{Materials and Methods}

\subsection{Data Collection}

Data were collected between the 19th and 24th of March 2020 through a cross-sectional quantitative survey. In accordance with the study design, recruitment and data collection were conducted by a professional market research agency in accordance with the European Society for Opinion and Marketing Research (ESOMAR) code of conduct using the Computer Assisted Web Interview (CAWI) technique. The study sample was recruited from an e-panel of ARC Market and Opinion Agency that included around 60,000 registered individuals. The recruitment criterion was age; the respondents were between 18 and 65 years of age. Quota selection regarding gender, age, place of residence, and region was used to ensure the representativeness of the Polish population. All participants provided voluntary consent to participate in the study in the form of a written informed consent. The study was conducted in accordance with the Helsinki Declaration [40].

\subsection{Outcome Variables}

Behaviors concerning food purchases in the COVID-19 pandemic were addressed by two questions: "Have you bought more food than usual in the last month?" (answers: yes/no) and "What products do you buy in larger quantities than before?" (answers: cheese, processed cheese, and blue cheese, meat and cold cuts; bread; fruit and vegetables; bottled water; flour and sugar; canned meat and fish; pasta, groats, and rice; and concentrates and frozen foods). Respondents were also asked about their fears regarding the availability of food, namely "Are you afraid that due to the current situation related to the spread of the coronavirus, there may be serious restrictions in access to food?" Opinions were scored on a 5-point scale: 1—definitely not; 2-rather not; 3-neither no nor yes; 4-rather yes; 5-definitely yes.

\subsection{Explanatory Variables}

The explanatory variables included opinions on changes in food availability during the COVID-19 pandemic, trust in institutions and people as sources of information regarding current situation, perceived stress, and demographics such as gender, age, and education.

Perceived changes in food availability were assessed by the following question: "Have you noticed changes in the availability of food in stores over the last month?" The respondent could give the following answers: no, I did not notice any changes or yes. For the second answer, the respondent indicated the nature of the perceived changes: the amount of food available on the market has slightly decreased; the amount of food available on the market has significantly decreased; or there are shortages of some food products in stores.

The question "To which extent do you trust the following people or institutions as sources of information on the current situation?" was used to assess the trust in institutions and people as a source of information on the current situation during the pandemic. Definition of trust was not given in the questionnaire. Thus, the participants, when answering the question, used a subjective understanding of this concept. The respondents determined their trust toward the following entities: the World Health Organization (WHO), the European Union Institutions, the Ministry of Health, other government agencies, scientists, doctors, producers of food, mass media, bloggers, and friends or relatives. Opinions were scored on a 5-point scale: $1-\mathrm{I}$ do not trust it/them at all; $2-\mathrm{I}$ rather do 
not trust it/them; 3-I neither trust nor distrust it/them; 4-I rather trust it/them; 5-I definitely trust it/them.

Perceived Stress Scale 4 (PSS-4) was used to assess individuals' perceived stress [41]. Participants were asked to indicate how often they felt or thought in a certain way: "In the last month, how often have you felt that you were unable to control the important things in your life?"; "In the last month, how often have you felt difficulties that were piling up so high that you could not overcome them?"; "In the last month, how often have you felt confident about your ability to handle your personal problems?"; and "In the last month, how often have you felt that things were going your way?". Opinions of the respondents were scored on a 5-point scale: never, almost never, sometimes, fairly often, and very often. The answers to questions 1 and 2 were coded as follows: 0 -never, 1 -almost never, 2-sometimes, 3-fairly often, 4-very often, while the answers to questions 3 and 4 were coded inversely: 0-very often, 1-fairly often, 2-sometimes, 3-almost never, 4-never. Cronbach's alpha coefficient for 4 items from this scale was 0.77 , which implies that the scale can be considered reliable. The overall score of perceived stress was calculated as a sum of all ratings (range from 0 to 16 points). Higher scores correlated with higher perceived stress.

\subsection{Statistical Analysis}

Descriptive statistics, including frequency distributions and cross-tabulations, were performed. The normality of variables was assessed by the Kolmogorov-Smirnov test. The mean values and standard deviation (SD) were calculated.

Factor analysis was used to identify factors based on the scores on trust in all information sources. The factors were rotated by an orthogonal (Varimax) transformation. The number of factors was determined on the basis of the following criteria: components with an eigenvalue of 1, a scree plot test, and the interpretability of the factors. Information sources with factor loadings of at least 0.50 were considered. The factorability of the data was confirmed with the Kaiser-Meyer-Olkin (KMO) measure of sampling adequacy and Bartlett's test of sphericity. The KMO value was found to be 0.775 , and Bartlett's test was significant at $p<0.0001$ [42]. The following three factors were identified: "External institutions, scientists and physicians", "Polish government institutions", and "Mass media and friends". The total variance explained was $62.9 \%$. The explained variance for the three factors was $37.4 \%, 14.0 \%$, and $11.4 \%$, respectively. The factor-loading matrix is presented in Table 1.

Table 1. Factor-loading matrix.

\begin{tabular}{lccc}
\hline \multicolumn{1}{c}{ Variables } & $\begin{array}{c}\text { “External Institutions, } \\
\text { Scientists and Physicians" } \\
\text { (Factor 1) }\end{array}$ & $\begin{array}{c}\text { "Polish Government } \\
\text { Institutions" } \\
\text { (Factor 2) }\end{array}$ & $\begin{array}{c}\text { "Mass Media } \\
\text { and Friends" } \\
\text { (Factor 3) }\end{array}$ \\
\hline World Health Organization (WHO) & $0.806^{*}$ & 0.194 & 0.041 \\
EU institutions & $0.723^{*}$ & 0.031 & 0.220 \\
Polish Ministry of Health & 0.290 & $0.829^{*}$ & 0.015 \\
Other government agencies & 0.112 & $0.895^{*}$ & 0.126 \\
Scientists & $0.733^{*}$ & 0.191 & 0.054 \\
Physicians & $0.716^{*}$ & 0.215 & 0.076 \\
Food producers & 0.303 & 0.473 & 0.422 \\
Mass media & 0.185 & 0.447 & $0.571^{*}$ \\
Bloggers & -0.052 & 0.177 & $0.794^{*}$ \\
Friends and relatives & 0.188 & -0.095 & $0.727^{*}$ \\
\hline
\end{tabular}

* Factor loadings $\geq 0.5$.

To estimate the likelihood of occurrence of fear caused by anticipated limited access to food due to the spread of coronavirus, a logistic regression model (model 1) was developed. The dependent variable was the fear of limited access to food, which was treated as the dichotomous variable (yes versus no). The independent variables entered into the model were age, perceived stress, and identified factors related to trust (i.e., "External institutions, scientists and physicians", "Polish government 
institutions", and "Mass media and friends") as continuous variables and perceived changes in food availability (dichotomous variable). To predict the purchase of a larger amount of food, another logistic regression model (model 2) was developed. The dependent variable was the purchase of a larger amount of food than usual in the month previous to the survey, which was treated as the dichotomous variable (yes versus no). The independent variables were the same as those used in the previous model plus the variable "fears of limited access to food", which was also entered into the model. Correlation coefficient and cross-tabulation using the chi-square test were employed during the variable selection. Correlations between the independent variables in the correlation matrix were low (range: 0.001-0.124), except for the correlation between factors expressing trust in institutions and people as a source of information in the current situation (range: 0.315-0.411). Multicollinearity was examined through the variance inflation factor (VIF) and tolerance. The minimum observed value of tolerance was 0.886 , which confirmed the lack of collinearity. The range of VIFs was 1.022-1.273, which did not confirm multicollinearity [43]. The variables were included in both models using the enter method. Nagelkerke's $\mathrm{R}^{2}$ was used to assess the quality of the models [44]. The values of Nagelkerke's $\mathrm{R}^{2}$ were 0.134 and 0.136 for models 1 and 2, respectively. Hypothesis $\mathrm{H} 0$ that all the parameters in the model are equal to 0 for both models was rejected at every level of significance, both for the likelihood ratio and the Wald statistics. The Hosmer-Lemeshow test was used to calculate the probabilities of all the observations divided into 10 groups. Odds ratios (ORs) and 95\% confidence intervals (95\% CI) for ORs were calculated. All analyses were performed using IBM SPSS Statistics for Windows, version 26.0 (IBM Corp., Armonk, NY, USA).

\section{Results}

\subsection{Study Sample}

The study sample consisted of 1033 participants (519 women and 514 men) aged between 18 and 65 years. Table 2 shows characteristics of the study sample. None of the variables differed from the value for the country as a whole.

Table 2. Study sample characteristics.

\begin{tabular}{|c|c|c|c|}
\hline Variables & & $N=1033 *$ & $\%$ \\
\hline \multirow[t]{2}{*}{ Gender } & Female & 519 & 50.2 \\
\hline & Male & 514 & 49.8 \\
\hline \multirow[t]{3}{*}{ Education } & Lower than upper secondary & 393 & 38.0 \\
\hline & Upper secondary & 382 & 37.0 \\
\hline & Higher & 258 & 25.0 \\
\hline \multirow[t]{3}{*}{ Place of residence } & Rural area & 395 & 38.2 \\
\hline & City $\leq 200,000$ residents & 419 & 40.6 \\
\hline & City $>200,000$ residents & 219 & 21.2 \\
\hline \multirow[t]{5}{*}{ Age } & $18-24$ years old & 155 & 15.0 \\
\hline & $25-34$ years old & 227 & 22.0 \\
\hline & $35-44$ years old & 238 & 23.0 \\
\hline & $45-54$ years old & 227 & 22.0 \\
\hline & $55-65$ years old & 186 & 18.0 \\
\hline Age in years (mean \pm standard deviation) & & \multicolumn{2}{|c|}{$39.9 \pm 13.1$} \\
\hline
\end{tabular}

${ }^{*} N$-number of participants.

\subsection{Consumers' Trust in Information Sources}

Study participants showed the highest trust in sources such as physicians, scientists, and Polish Ministry of Health with regard to information about the situation during the COVID-19 pandemic. The lowest trust was recorded for bloggers, mass media, and government institutions other than the Ministry of Health. "External institutions, scientists, and physicians" was considered the most trusted 
source of information regarding the situation related to the COVID-19 pandemic, while "Mass media and friends" was the least trusted source of information (Table 3).

Table 3. Consumers' trust in selected sources of information on the COVID-19 pandemic.

\begin{tabular}{lllc}
\hline \multicolumn{1}{c}{ Factor } & \multicolumn{1}{c}{ Variables } & $\begin{array}{c}\text { Mean }{ }^{*} \pm \text { Standard } \\
\text { Deviation }\end{array}$ & $\begin{array}{c}\text { Factor (Mean ** } \pm \\
\text { Standard Deviation) }\end{array}$ \\
\hline \multirow{2}{*}{ "External institutions, } & World Health Organization (WHO) & $3.6 \pm 0.95$ & \\
scientists, & EU institutions & $3.2 \pm 1.01$ & $3.6 \pm 0.73$ \\
and physicians" & Scientists & $3.7 \pm 0.90$ & \\
“Polish government & Physicians & $3.9 \pm 0.91$ & $3.2 \pm 0.97$ \\
institutions" & Polish Ministry of Health & $3.7 \pm 1.08$ & \\
"Mass media & Other government agencies & $3.0 \pm 1.04$ & $3.0 \pm 0.71$ \\
and friends" & Mass media & $2.8 \pm 1.02$ & \\
& Bloggers & $2.7 \pm 0.98$ & \\
\hline
\end{tabular}

* Five-point scale: 1 -I do not trust it/them at all; 2-I do not really trust it/them; 3 -I neither trust nor distrust it/them; 4-I rather trust it/them; 5-I definitely trust it/them. ${ }^{* *}$ Calculated after summing the scores for individual items within a given factor and dividing by the number of items in it (range 1-5).

\subsection{Perceived Stress}

The sum of the scores representing the perceived stress ranged from 0 to 16 points, and the mean score was $6.8 \pm 3.03$. Extreme results were achieved for 25 people: 19 respondents obtained 0 points (lack of stress) and 6 respondents obtained 16 points (very high level of stress).

\subsection{Perception of Food Availability during the COVID-19 Pandemic}

Only $12.6 \%$ of respondents did not notice any changes in food availability in the month preceding the survey. More than $70 \%$ of respondents observed a decrease in the amount of food available on the market, while shortages of some foods were noticed by $16.2 \%$ of respondents (Table 4 ). The largest group of respondents did not anticipate restrictions in access to food due to the spread of the pandemic (definitely not and rather not: $43.7 \%$ ), while the opposite opinion was expressed by $39.0 \%$ of the surveyed sample (Table 4). The mean value was 3.0, with a standard deviation of 1.13.

Table 4. Opinions on availability of food during the COVID-19 pandemic.

\begin{tabular}{|c|c|c|c|}
\hline & Variable & $N^{*}$ & $\%$ \\
\hline \multirow{4}{*}{$\begin{array}{l}\text { Perceived changes in } \\
\text { food availability in } \\
\text { the previous month }\end{array}$} & No, I did not notice any changes & 131 & 12.6 \\
\hline & Yes, the amount of food available on the market has slightly decreased & 367 & 35.5 \\
\hline & $\begin{array}{l}\text { Yes, the amount of food available on the market has } \\
\text { significantly decreased }\end{array}$ & 167 & 16.2 \\
\hline & Yes, there are shortages of some food products in stores & 369 & 35.7 \\
\hline \multirow{5}{*}{$\begin{array}{l}\text { Fears of limited } \\
\text { access to food as the } \\
\text { pandemic spreads }\end{array}$} & Definitely not & 58 & 5.6 \\
\hline & Rather not & 394 & 38.1 \\
\hline & Neither no nor yes & 179 & 17.3 \\
\hline & Rather yes & 308 & 29.8 \\
\hline & Definetely yes & 95 & 9.2 \\
\hline
\end{tabular}

${ }^{*} N$-number of participants.

\subsection{Purchase of Food in Larger Quantities}

It was found that $44.0 \%$ respondents declared that they purchased larger amounts of food than usual in the month previous to the survey. They bought larger quantities of pasta, groats, and rice (33.0\% of total sample); flour and sugar (27.9\%); bottled water (20.7\%); and meat and cold meats (20.4\%). In the group of people who declared larger purchases, the proportion of people buying these products was as follows: $75.0 \%, 63.4 \%, 47.0 \%$, and $46.4 \%$, respectively. The smallest number of respondents 
indicated the purchase of larger amounts of fruits and vegetables, frozen foods, cheese, melted cheese, and blue cheese (Table 5).

Table 5. Foods purchased in larger quantities during the COVID-19 pandemic.

\begin{tabular}{|c|c|c|c|c|c|c|}
\hline \multirow{3}{*}{ Food Groups } & \multirow{2}{*}{\multicolumn{2}{|c|}{$\begin{array}{l}\text { Total Sample } \\
\left(N=1033^{*}\right)\end{array}$}} & \multicolumn{4}{|c|}{$\begin{array}{c}\text { Group Declaring Purchasing Larger Quantities of Food than } \\
\text { Usual in the Previous Month }\left(N=454^{*}\right)\end{array}$} \\
\hline & & & \multicolumn{2}{|c|}{$\begin{array}{l}\text { Product Purchased in Larger } \\
\text { Quantities than Usual }\end{array}$} & \multicolumn{2}{|c|}{$\begin{array}{l}\text { Product not Purchased in } \\
\text { Larger Quantities than Usual }\end{array}$} \\
\hline & $N^{*}$ & $\%$ & $N$ & $\%$ & $N$ & $\%$ \\
\hline Pasta, groats, and rice & 340 & 33.0 & 340 & 75.0 & 114 & 25.0 \\
\hline Flour and sugar & 288 & 27.9 & 288 & 63.4 & 166 & 36.6 \\
\hline Bottled water & 213 & 20.7 & 213 & 47.0 & 241 & 53.0 \\
\hline Meat and cold meats & 211 & 20.4 & 211 & 46.4 & 243 & 53.6 \\
\hline Canned meat and fish & 188 & 18.2 & 188 & 41.4 & 266 & 58.6 \\
\hline Bread & 145 & 14.1 & 145 & 32.0 & 309 & 68.0 \\
\hline Concentrates & 146 & 14.0 & 146 & 32.2 & 308 & 67.8 \\
\hline Cheese, blue cheese, and melted cheese & 124 & 12.0 & 124 & 27.3 & 330 & 72.7 \\
\hline Frozen foods & 124 & 12.0 & 124 & 27.4 & 330 & 72.6 \\
\hline Fruits and vegetables & 83 & 8.0 & 83 & 18.2 & 371 & 81.8 \\
\hline
\end{tabular}

\subsection{Predictors of Consumers' Fears and Purchase Behaviors during the COVID-19 Pandemic}

Experiencing fears of limited access to food as the pandemic spreads (model 1) was more likely among people who felt more stress, those who had greater trust in sources of information on current situation, such as mass media, bloggers, and friends and relatives ("Mass media and friends"), and those who perceived changes in food availability in the month preceding the survey (Table 6). Each subsequent point indicating perceived stress increased the likelihood of experiencing fear by 16\% (OR: 1.16; 95\% CI: 1.11-1.22). Each subsequent point indicating trust in "Mass media and friends" increased the likelihood of experiencing fear by 50\% (OR: 1.50; 95\% CI: 1.22-1.85). However, the perceived changes in food availability were the strongest predictor of experiencing fears of limited access to food. Perception of such changes increased the likelihood of the occurrence of fears by more than three times (OR: 3.19; 95\% CI: 2.03-5.01). In contrast, experiencing fears of limited access to food as the pandemic spreads was less likely among people who had greater trust in "Polish government institutions" (OR: 0.78; 95\% CI: 0.66-0.91) (Table 6).

Table 6. Odds ratios (OR; 95\% CI) of fears and purchase behaviors of the study sample.

\begin{tabular}{|c|c|c|c|c|}
\hline Variables & \multicolumn{2}{|c|}{$\begin{array}{l}\text { Fears of Limited Access to Food } \\
\text { as the Pandemic Spreads } \\
\text { (Model 1) }\end{array}$} & \multicolumn{2}{|c|}{$\begin{array}{c}\text { Purchase of Larger than Usual Quantities } \\
\text { of Food in the Previous Month } \\
\text { (Model 2) }\end{array}$} \\
\hline Age (in years) & 1 & $0.99(0.98-1.00)$ & 1 & $1.00(0.99-1.021)$ \\
\hline Perceived stress (in points) & 1 & $1.16^{* * *}(1.11-1.22)$ & 1 & $1.09^{* * *}(1.04-1.14)$ \\
\hline "Polish government institutions" & 1 & $0.78^{* *}(0.66-0.91)$ & 1 & $0.91(0.77-1.06)$ \\
\hline "Mass media and friends" & 1 & $1.50 * * *(1.22-1.85)$ & 1 & $1.46^{* * *}(1.19-1.81)$ \\
\hline $\begin{array}{l}\text { Perceived changes in food availability } \\
\text { in the previous month }\end{array}$ & 1 & $3.19 * * *(2.03-5.01)$ & 1 & $1.81 * *(1.19-2.77)$ \\
\hline Fears of limited access to food & - & - & 1 & $2.30 * * *(1.75-3.03)$ \\
\hline
\end{tabular}

Similar to model 1, the purchase of larger quantities of food than usual in the month preceding the study was more likely among people with higher level of stress; those who had higher trust in sources of information on the current situation during the pandemic, such as mass media, bloggers, and friends and relatives ("Mass media and friends"); and those who perceived changes in food availability in the previous month (Table 6). Each subsequent point indicating perceived stress increased the likelihood 
of experiencing fear by 9\% (OR: 1.09; 95\% CI: 1.04-1.14). Each subsequent point indicating trust in "Mass media and friends" increased the likelihood of experiencing fear by 46\% (OR: 1.46; 95\% CI: 1.19-1.81). Perception of changes in food availability in the previous month increased the likelihood of purchasing larger quantities of food than usual in the previous month by $81 \%$ (OR: $1.81 ; 95 \%$ CI: 1.19-2.77). The strongest predictor of purchasing larger quantities of food than usual in the month preceding the survey was experiencing fears of limited access to food as the pandemic spreads, which increased the likelihood of such behavior by 130\% (OR: 2.30; 95\% CI: 1.75-3.03) (Table 6).

\section{Discussion}

Shortages or reduced food supplies in grocery stores were noted by the study participants (35.7\% and $51.7 \%$, respectively) and were also confirmed in other studies $[45,46]$, which may be attributed to a change in existing purchasing behavior. However, only $44 \%$ of the respondents reported about major food purchases, which may indicate that other people did not feel threatened by the potential inability to meet their basic needs [47]. On the other hand, perceived changes in the food supply could be treated by other consumers as temporary, which was in line with the explanations offered by government institutions $[15,45,46]$. The obtained results showed that the response of Polish consumers on the food market in the initial phase of the pandemic was similar to that noted in other countries, i.e., a stock-up mentality began to appear $[48,49]$. Although supermarkets in most countries have introduced changes to reduce panic buying and to minimize the spread of COVID-19 while shopping, the panic-stricken behaviors were not completely eliminated [50]. Thus, unless policy makers can find a way to restore a sense of security, the cycle of panic buying, hoarding, and scarcity may continue to exist [37].

Findings of the present study confirmed the relationship between perceived stress and both fears of limited access to food and purchases of larger quantities of food than usual [51]. Perceived stress was a stronger predictor of the fears than of the purchase behaviors. In previous pre-pandemic studies, different mean values for stress perception were reported when PSS-4 scale was used, for example, the mean values were 6.11 in a British sample [52], 5.43 in a Spanish sample [53], and 6.27 in a Korean sample [54]. The mean value of perceived stress in our sample (6.83) was higher than that reported in the abovementioned studies. This can be explained by the study period, i.e., the beginning of the pandemic, which was associated with many ambiguities as well as terrible information about the situation in other countries that were more affected by the coronavirus at that time (China and Italy). It could have been expected that the situation in Poland and around the world related to the pandemic during the study would cause much higher stress. However, the measurement tool (PSS-4), which examines coping in general [53], without referring directly to a pandemic, could have had a decisive impact on the obtained results. Thus, implementing other tools to measure the level of stress during pandemic is also recommended. Despite this limitation, the obtained results showing an increasing likelihood of occurrence of both fear associated with limited food availability and the purchase of larger than usual quantities of food with the increase in perceived stress, require the latter to be focused upon to limit the negative effects of a pandemic.

Experiencing fear during a pandemic, which is caused amongst others by changes in food availability, raises the question of the importance of available information and trust in their sources in reducing this negative emotion and its consequences, e.g., panic-stricken purchasing behavior. Trust as an element of social capital [55] has been found to be important in risk communication and management $[25,56]$, in interactions among people, and in civic engagement [57]. Thus, trust gains importance during a pandemic because it facilitates the transformation of available passive information into information that is usable in decision-making [58]. Moreover, according to previous studies, trust plays an important role in influencing attitudes and purchasing decisions regarding food products $[25,59,60]$. In the present study, researchers' attention concerning trust was focused solely on relationships between individuals (interpersonal or relational) and between individuals and institutions as sources of information on the pandemic situation. However, trust was measured only at the general level, without recalling different spheres of the pandemic situation. External institutions represented by WHO and EU institutions and 
experts who are most involved in combating the pandemic, i.e., physicians and scientists, were recognized as the most trusted sources of information ("External institutions, scientists, and physicians" —mean $3.6 \pm 0.73)$. Public trust in science has remained stable for almost 50 years $[60,61]$ and is still strong. However, the perception of the "experts" that is also continuously changing during the pandemic may cause a decline in trust [62]. An erosion of public trust in expertise in general, rather than in science, is currently observed [63]. The traditional roles of "information gathering" experts are diminished by the accelerating tempo of dissemination of information regardless of quality, which is constantly being observed in mass media. This implies that the recipient of the message has a problem in differentiating between valuable and worthless information, which further reduces public trust in expertise. Moreover, the media tend to sensationalize the reality or present contradictory information, therefore creating distrust in them, which often results from the dramatization of the received information [64]. In the present study, trust in "Mass media and friends" was the lowest compared to that in other sources of information, which may confirm the above discussed limitations of this source of information and its public perception. However, mass media together with bloggers, friends, and relatives were the predictors of both fears of limited access to food and purchase of larger than usual quantities of food as the pandemic spreads. Greater trust in these sources of information increased the likelihood of participants' fear of food shortages and their food-gathering behaviors.

Conversely, greater trust in national government institutions reduced the likelihood of participants' fears of food shortages, but this trust was not a predictor of behavior associated with the purchase of larger amounts of food. The positive effect of trust in government institutions was also observed in other studies $[65,66]$. In our study, the trust in Polish government was relatively low (mean $3.2 \pm 0.97$ ). However, the trust in the Polish Ministry of Health $(3.7 \pm 1.08)$ was higher than that in other government agencies $(3.0 \pm 1.04)$ and European institutions $(3.2 \pm 1.01)$, and at the same time, it was almost equal to trust in WHO (3.66 \pm 0.95$)$. High trust in WHO may be linked to its daily reports assessing not only the overall extent of the crisis but also its progression [67]. In the case of the COVID-19 pandemic, however, many individuals raised their voices to undermine the credibility of health institutions, which can be difficult to rebuild especially during a pandemic [68]. Thus, monitoring the level of public trust as the pandemic progresses is recommended in future studies in order to counteract the decline in trust in health institutions, which are of great importance in the pandemic.

According to the Trust and Confidence Model, trust can indirectly influence the acceptance of recommendations $[35,36]$. Nevertheless, it is noted that the positive effect of trust does not imply that all recommendations are followed. For example, trust in the government positively influenced an intention to accept vaccination, but not to an intention to adopt protective measures (such as adopting additional hygienic precautions) [65], which can significantly limit the effect of governmental measures to control the spread of pandemic by imposing many restrictions. In addition, the effect of trust in government institutions may change as the pandemic evolves. For example, during the influenza A (H1N1) pandemic, a significant reduction in government trust was noted as the pandemic continued $[38,65]$. Decreased trust in the government's ability to handle the threat may result from conflicting messages that can create skepticism about public health warnings [31,36]. People believed that at the beginning of the pandemic, information was hidden or kept secret from them, while most believed that the government later exaggerated the situation $[69,70]$. Thus, responsible communication regarding the crisis is required to maintain and build trust in the government during a pandemic [35].

Although the results of the present study refer to the beginning of the pandemic, they have shown how much food purchasing behaviors in uncertain times depend on the level of perceived stress and trust in various sources of information. A highly dynamic situation in the pandemic, in terms of illnesses and the level of health care, food market situation, people's mental health, and relation to trust in information sources, requires continuous monitoring. 
The present study provides an insight into how a state of epidemic combined with lockdown can affect food purchase behaviors; however, there are some limitations that need to be considered. First, the study used an approach that provides a general summary of the changes in food buying behaviors in the very early stage of a pandemic, i.e., purchase of larger amounts of food and its determinants. Thus, the results cannot be interpreted in the context of long-term effects. This suggests the need for cautious data interpretation and calls for further studies in this field. The measurement tool (PSS-4) concerns coping in general [53], without referring directly to a pandemic, which is also a limitation of the present study. Application of other tools to measure the level of stress during pandemic is recommended in further research. Lastly, this was a cross-sectional study that did not allow for an assessment of the causality of relationships between the variables. Our findings are specific to the Polish population at a certain stage of the COVID-19 pandemic and should not be generalized to populations of other cultural backgrounds. However, the observations could be of potential use beyond Poland, not only in designing further research that allows to observe changes during the pandemic but also in developing strategies to improve the effectiveness of communication in pandemic conditions, taking into account the public trust.

The strength of our study is the fact that the survey was conducted in the beginning of the COVID-19 pandemic in Poland, just as the lockdown was being introduced. Therefore, the bias of self-reported food purchase behaviors was not influenced by experiences from the further period of the pandemic.

\section{Conclusions}

The present study revealed less trust in media than in other sources of information on the COVID-19 pandemic in Poland. Moreover, trust in information from media and other people (friends and bloggers) increased the likelihood of fears of limited access to food as the pandemic continued to spread and increased the likelihood of purchasing larger quantities of food than usual. Therefore, government institutions may have difficulty in disseminating pandemic-related recommendations through media organizations, due to relatively low trust in them and their role in not only increasing the likelihood of occurrence of fears regarding food availability but also in causing panic-stricken food buying behaviors. Thus, it is necessary for government agencies, which consider the opinions of physicians and scientists when formulating their policies, to communicate with the public through more direct channels, including government-operated websites, television, and radio networks. Thus, it may also be possible to reduce the predicted effect of the "Mass media and friends" of increasing the likelihood of occurrence of food availability fears and of food purchase behaviors related to uncertainty in the pandemic. In the first stage of the COVID-19 pandemic, the likelihood of occurrence of both fears regarding food availability as the pandemic spreads and the purchase of larger quantities of food than usual increased when higher perceived stress was claimed. Therefore, further studies are required to understand whether COVID-19-related lockdown has resulted in long-term changes both in the level of public trust toward information sources and in food purchase behaviors. The latter can promote long-term reinforcement of adverse eating habits and related health problems. Knowing how people function in the food sphere during a pandemic is also pertinent to understand the role that food may play in future epidemic quarantines.

Author Contributions: M.J.-Z. made substantial contributions to the study conception and design; M.J.-Z. was involved in the data acquisition; M.J.-Z. analyzed and interpreted the data; M.J.-Z. and M.P. wrote the manuscript; M.J.-Z., M.P., and M.K. were involved in critically revising the manuscript, and have given their approval to the manuscript submitted. All authors have read and agreed to the published version of the manuscript.

Funding: The research was financed by the Polish Ministry of Science and Higher Education with funds from the Faculty of Human Nutrition and Consumer Sciences, Warsaw University of Life Sciences (WULS), for scientific research.

Acknowledgments: Thanks are expressed to the research agency ARC Market and Opinion and the participants for their contributions to the study.

Conflicts of Interest: The authors declare no conflict of interest. 


\section{References}

1. Burki, T. Outbreak of coronavirus disease 2019. Lancet Infect. Dis. 2020, 20, 292-293. [CrossRef]

2. Di Renzo, L.; Gualtieri, P.; Pivari, F.; Soldati, L.; Attinà, A.; Cinelli, G.; Leggeri, C.; Caparello, G.; Barrea, L.; Scerbo, F.; et al. Eating habits and lifestyle changes during COVID-19 lockdown: An Italian survey. J. Transl. Med. 2020, 18, 229. [CrossRef]

3. Legido-Quigley, H.; Asgari, N.; Teo, Y.Y.; Leung, G.M.; Oshitani, H.; Fukuda, K.; Cook, A.R.; Hsu, L.Y.; Shibuya, K.; Heymann, D. Are high-performing health systems resilient against the COVID-19 epidemic? Lancet 2020, 395, 848-850. [CrossRef]

4. Kowalczyk, S. Sektor żywnościowy w Czasach Pandemii Koronawirusa. Available online: https://ssl-kolegia. sgh.waw.pl/pl/KNoP/struktura/IRiK/instytut/sklad/Documents/Pandemic_food_SKowalczyk.pdf (accessed on 17 July 2020).

5. Kouzy, R.; Abi Jaoude, J.; Kraitem, A.; El Alam, M.B.; Karam, B.; Adib, E.; Zarka, J.; Traboulsi, C.; Akl, E.; Baddour, K. Coronavirus Goes Viral: Quantifying the COVID-19 Misinformation Epidemic on Twitter. Cureus 2020, 12, e7255. [CrossRef] [PubMed]

6. Mian, A.; Khan, S. Coronavirus: The spread of misinformation. BMC Med. 2020, 18, 89. [CrossRef] [PubMed]

7. Li, L.; Zhang, Q.; Wang, X.; Zhang, J.; Wang, T.; Gao, T.L.; Duan, W.; Tsoi, K.K.F.; Wang, F.Y. Characterizing the Propagation of Situational Information in Social Media during COVID-19 Epidemic: A Case Study on Weibo. IEEE Trans. Comput. Soc. Syst. 2020, 7, 556-562. [CrossRef]

8. Fu, K.; Zhu, Y. Did the world overlook the media's early warning of COVID-19? J. Risk Res. 2020, 1-5. [CrossRef]

9. Allen, J.G.; Marr, L.C. Recognizing and controlling airborne transmission of SARS-CoV-2 in indoor environments. Indoor Air 2020, 30, 557-558. [CrossRef]

10. Morawska, L.; Tang, J.W.; Bahnfleth, W.; Bluyssen, P.M.; Boerstra, A.; Buonanno, G.; Cao, J.; Dancer, S.; Floto, A.; Franchimon, F.; et al. How can airborne transmission of COVID-19 indoors be minimised? Environ. Int. 2020, 142, 105832. [CrossRef]

11. Hiroshi, N.; Hitoshi, O.; Tetsuro, K.; Tomoya, S.; Sunagawa, T.; Matsui, T.; Wakita, T. Closed environments facilitate secondary transmission of coronavirus disease 2019 (COVID-19). medRxiv 2020. [CrossRef]

12. Sidor, A.; Rzymski, P. Dietary choices and habits during COVID-19 lockdown: Experience from Poland. Nutrients 2020, 12, 1657. [CrossRef] [PubMed]

13. Niles, M.; Bertmann, F.; Morgan, E.; Wentworth, T.; Biehl, E. Food Access and Security during Coronavirus: A Vermont Study. College of Agriculture and Life Sciences Faculty Publications 21. Available online: https://scholarworks.uvm. edu/calsfac/21 (accessed on 10 September 2020).

14. Kolodko, G.W. Reform, Stabilization Policies, and Economic Adjustment in Poland; World Institute for Development Economics Reasearch of the United Nations University: Helsinki, Finland, 1989.

15. Galanakis, C.M. The Food Systems in the Era of the Coronavirus (COVID-19) Pandemic Crisis. Foods 2020, 9, 523. [CrossRef] [PubMed]

16. Oliveira, T.C.; Abranches, M.V.; Lana, R.M. Food (in)security in Brazil in the context of the SARS-CoV-2 pandemic. Cadernos de Saúde Pública 2020, 36, e00055220. [CrossRef]

17. Dannenberg, P.; Fuchs, M.; Riedler, T.; Wiedemann, C. Digital Transition by COVID-19 Pandemic? The German Food Online Retail. Tijdschrift voor Economische en Sociale Geografie 2020, 111, 543-560. [CrossRef]

18. Pfefferbaum, B.; North, C.S. Mental Health and the Covid-19 Pandemic. N. Engl. J. Med. 2020, 383, 510-512. [CrossRef]

19. Mazza, C.; Ricci, E.; Biondi, S.; Colasanti, M.; Ferracuti, S.; Napoli, C.; Roma, P. A nationwide survey of psychological distress among italian people during the covid-19 pandemic: Immediate psychological responses and associated factors. Int. J. Environ. Res. Public Health 2020, 17, 3165. [CrossRef]

20. Brooks, S.K.; Webster, R.K.; Smith, L.E.; Woodland, L.; Wessely, S.; Greenberg, N.; Rubin, G.J. The psychological impact of quarantine and how to reduce it: Rapid review of the evidence. Lancet 2020, 395, 912-920. [CrossRef]

21. Wong, S.L. China Warns that Spread of Deadly Virus will Accelerate. Available online: https://www.ft.com/ content/7bb597c8-37-11ea-a047-eae9bd51ceba (accessed on 2 May 2020).

22. Yau, Y.H.C.; Potenza, M.N. Stress and eating behaviors. Minerva Endocrinol. 2013, 38, 255-267. 
23. Mattioli, A.V.; Ballerini Puviani, M.; Nasi, M.; Farinetti, A. COVID-19 pandemic: The effects of quarantine on cardiovascular risk. Eur. J. Clin. Nutr. 2020, 74, 852-855. [CrossRef]

24. Finset, A.; Bosworth, H.; Butow, P.; Gulbrandsen, P.; Hulsman, R.L.; Pieterse, A.H.; Street, R.; Tschoetschel, R.; van Weert, J. Effective health communication-A key factor in fighting the COVID-19 pandemic. Patient Educ. Couns. 2020, 103, 873-876. [CrossRef]

25. Henderson, J.; Ward, P.R.; Tonkin, E.; Meyer, S.B.; Pillen, H.; McCullum, D.; Toson, B.; Webb, T.; Coveney, J.; Wilson, A. Developing and Maintaining Public Trust During and Post-COVID-19: Can We Apply a Model Developed for Responding to Food Scares? Front. Public Health 2020, 8, 369. [CrossRef]

26. Webster, A. Consumer Survey: A Second Look at COVID-19's Impact on Food Purchasing, Eating Behaviors and Perceptions of Food Safety. Available online: https://foodinsight.org/consumer-survey-a-second-lookat-covid-19s-impact-on-food-purchasing-eating-behaviors/ (accessed on 30 June 2020).

27. McFadden, S.A.M.; Malik, A.A.; Aguolu, O.G.; Willebrand, K.S.; Omer, S.B. Perceptions of the adult US population regarding the novel coronavirus outbreak. PLOS ONE 2020, 15, e0231808. [CrossRef]

28. Gambetta, D. Trust Making and Breaking Cooperative Relations; Basil Blackwell: Oxford, UK, 1988.

29. Wilson, A.; Coveney, J.; Henderson, J.; Meyer, S.; Calnan, M.; Caraher, M.; Webb, T.; Elliott, A.; Ward, P. Trust makers, breakers and brokers: Building trust in the Australian food system. BMC Public Health 2013, 13, 229. [CrossRef] [PubMed]

30. Giddens, A. Modernity and Self-Identity: Self and Society in the Late Modern Age; Stanford University Press: Stanford, CA, USA, 1991.

31. Smith, R.D. Responding to global infectious disease outbreaks: Lessons from SARS on the role of risk perception, communication and management. Soc. Sci. Med. 2006, 63, 3113-3123. [CrossRef]

32. Brug, J.; Aro, A.R.; Oenema, A.; De Zwart, O.; Richardus, J.H.; Bishop, G.D. SARS risk perception, knowledge, precautions, and information sources, The Netherlands. Emerg. Infect. Dis. 2004, 10, 1486-1489. [CrossRef] [PubMed]

33. Love, B.; Mackert, M.; Silk, K. Consumer Trust in Information Sources: Testing an Interdisciplinary Model. SAGE Open 2013, 1-13. [CrossRef]

34. Rubin, G.J.; Amlôt, R.; Page, L.; Wessely, S. Public perceptions, anxiety, and behaviour change in relation to the swine flu outbreak: Cross sectional telephone survey. BMJ 2009, 339, b2651. [CrossRef]

35. Siegrist, M.; Earle, T.C.; Gutscher, H. Test of a trust and confidence model in the applied context of electromagnetic field (EMF) risks. Risk Anal. 2003, 23, 705-716. [CrossRef]

36. Vaughan, E.; Tinker, T. Effective health risk communication about pandemic influenza for vulnerable populations. Am. J. Public Health 2009, 99, S324-S332. [CrossRef]

37. Siegrist, M.; Zingg, A. The role of public trust during pandemics: Implications for crisis communication. Eur. Psychol. 2014, 19, 23-32. [CrossRef]

38. Bangerter, A.; Krings, F.; Mouton, A.; Gilles, I.; Green, E.G.T.; Clémence, A. Longitudinal Investigation of Public Trust in Institutions Relative to the 2009 H1N1 Pandemic in Switzerland. PLoS ONE 2012, 7, e49806. [CrossRef]

39. Prati, G.; Pietrantoni, L.; Zani, B. Compliance with recommendations for pandemic influenza H1N1 2009: The role of trust and personal beliefs. Health Educ. Res. 2011, 26, 761-769. [CrossRef]

40. World Medical Association declaration of Helsinki: Ethical principles for medical research involving human subjects. JAMA—J. Am. Med. Assoc. 2013, 310, 2191-2194. [CrossRef]

41. Cohen, S.; Kamarck, T.; Mermelstein, R. A global measure of perceived stress. J. Health Soc. Behav. 1983, 24, 385-396. [CrossRef] [PubMed]

42. Field, A. Discovering Statistics Using SPSS, 3rd ed.; Sage Publications: London, UK, 2009.

43. Schreiber-Gregory, D.N.; Jackson, H.M. Multicollinearity: What Is It, Why Should We Care, and How Can It Be Controlled? Available online: https://support.sas.com/resources/papers/proceedings17/1404-2017.pdf (accessed on 10 December 2018).

44. Nagelkerke, N.J.D. A note on a general definition of the coefficient of determination. Biometrika 1991, 78, 691-692. [CrossRef]

45. Hobbs, J.E. Food supply chains during the COVID-19 pandemic. Can. J. Agric. Econ. 2020, 1-6. [CrossRef] 
46. Ker, A.P.; Cardwell, R. Introduction to the special issue on COVID-19 and the Canadian agriculture and food sectors: Thoughts from the pandemic onset. Can. J. Agric. Econ. 2020, 1-4. [CrossRef]

47. Sheth, J. Impact of Covid-19 on consumer behavior: Will the old habits return or die? J. Bus. Res. 2020, 117, 280-283. [CrossRef]

48. Mao, F. Coronavirus Panic: Why are People Stockpiling Toilet Paper? Available online: https://www.bbc. com/news/world-australia-51731422 (accessed on 26 June 2020).

49. Zwanka, R.J.; Buff, C. COVID-19 Generation: A Conceptual Framework of the Consumer Behavioral Shifts to Be Caused by the COVID-19 Pandemic. J. Int. Consum. Mark. 2020, 1-10. [CrossRef]

50. Martin-Neuninger, R.; Ruby, M.B. What Does Food Retail Research Tell Us About the Implications of Coronavirus (COVID-19) for Grocery Purchasing Habits? Front. Psychol. 2020, 11, 1448. [CrossRef]

51. Rodríguez-Martín, B.C.; Meule, A. Food craving: New contributions on its assessment, moderators, and consequences. Front. Psychol. 2015, 6, 21. [CrossRef]

52. Warttig, S.L.; Forshaw, M.J.; South, J.; White, A.K. New, normative, English-sample data for the Short Form Perceived Stress Scale (PSS-4). J. Health Psychol. 2013, 18, 1617-1628. [CrossRef]

53. Vallejo, M.A.; Vallejo-Slocker, L.; Fernández-Abascal, E.G.; Mañanes, G. Determining factors for stress perception assessed with the Perceived Stress Scale (PSS-4) in Spanish and other European samples. Front. Psychol. 2018, 3, 37. [CrossRef]

54. Lee, E.H.; Chung, B.Y.; Suh, C.H.; Jung, J.Y. Korean versions of the Perceived Stress Scale (PSS-14, 10 and 4): Psychometric evaluation in patients with chronic disease. Scand. J. Caring Sci. 2015, 29, 183-192. [CrossRef] [PubMed]

55. Newman, C.; Briggeman, B.C. Farmers' perceptions of building trust. Int. Food Agribus. Manag. Rev. 2016, 19,57-76. [CrossRef]

56. Earle, T.C.; Siegrist, M.; Gutscher, H. Trust, Risk Perception, and the TCC Model of Cooperation. In Trust in Cooperative Risk Management: Uncertainty and Scepticism in the Public Mind; Siegrist, M., Earle, T.C., Gutscher, H., Eds.; Earthscan: London, UK, 2007; pp. 1-49.

57. Robbins, B.G. What is Trust? A Multidisciplinary Review, Critique, and Synthesis. Sociol. Compass 2016, 10, 972-986. [CrossRef]

58. Fisher, R. "A gentleman's handshake": The role of social capital and trust in transforming information into usable knowledge. J. Rural Stud. 2013, 31, 13-22. [CrossRef]

59. Hobbs, J.E.; Goddard, E. Consumers and trust. Food Policy 2015, 52, 71-74. [CrossRef]

60. Tanaka, K. Seven samurai to protect "our" food: The reform of the food safety regulatory system in Japan after the BSE crisis of 2001. Agric. Human Values 2008, 25, 567-580. [CrossRef]

61. Funk, C.; Kennedy, B. Public Confidence in Scientists Has Remained Stable for Decades. Available online: https://www. pewresearch.org/fact-tank/2019/03/22/public-confidence-in-scientists-has-remained-stable-for-decades/ (accessed on 8 April 2018).

62. Garza, C.; Stover, P.J.; Ohlhorst, S.D.; Field, M.S.; Steinbrook, R.; Rowe, S.; Woteki, C.; Campbell, E. Best practices in nutrition science to earn and keep the public's trust. Am. J. Clin. Nutr. 2019, 109, 225-243. [CrossRef]

63. Nichols, T. How America lost faith in expertise: And why that's a giant problem. Foreign Aff. 2017, 96, 60-73.

64. Taha, S.A.; Matheson, K.; Anisman, H. The 2009 H1N1 influenza pandemic: The role of threat, coping, and media trust on vaccination intentions in Canada. J. Health Commun. 2013, 18, 278-290. [CrossRef]

65. Van Der Weerd, W.; Timmermans, D.R.M.; Beaujean, D.J.M.A.; Oudhoff, J.; Van Steenbergen, J.E. Monitoring the level of government trust, risk perception and intention of the general public to adopt protective measures during the influenza A (H1N1) pandemic in the Netherlands. BMC Public Health 2011, 11, 575. [CrossRef] [PubMed]

66. Christensen, T.; Lægreid, P. Trust in Government: The Relative Importance of Service Satisfaction, Political Factors, and Demography. Public Perform. Manag. Rev. 2005, 28, 487-511. [CrossRef]

67. World Health Organization Coronavirus Disease (COVID-2019) Situation Reports. Available online: https: //www.who.int/emergencies/diseases/novel-coronavirus-2019/situation-reports (accessed on 28 April 2020).

68. Cori, L.; Bianchi, F.; Cadum, E.; Anthonj, C. Risk perception and covid-19. Int. J. Environ. Res. Public Health 2020, 17, 3114. [CrossRef] [PubMed] 
69. Bults, M.; Beaujean, D.J.M.A.; De Zwart, O.; Kok, G.; Van Empelen, P.; Van Steenbergen, J.E.; Richardus, J.H.; Voeten, H.A.C.M. Perceived risk, anxiety, and behavioural responses of the general public during the early phase of the Influenza A (H1N1) pandemic in the Netherlands: Results of three consecutive online surveys. BMC Public Health 2011, 11, 2. [CrossRef] [PubMed]

70. Seale, H.; McLaws, M.L.; Heywood, A.E.; Ward, K.F.; Lowbridge, C.P.; Van, D.; Gralton, J.; MacIntyre, C.R. The community's attitude towards swine flu and pandemic influenza. Med. J. Aust. 2009, 191, 267-269. [CrossRef]

(C) 2020 by the authors. Licensee MDPI, Basel, Switzerland. This article is an open access article distributed under the terms and conditions of the Creative Commons Attribution (CC BY) license (http://creativecommons.org/licenses/by/4.0/). 